\title{
The Guiding Role of SPOC Teaching in the Use of Mobile Phones for Undergraduate
}

\author{
Jingren Cao \\ College of Electrical and Information Engineering, Beihua University, Jilin 132021, China \\ 334916434@qq.com
}

\begin{abstract}
Keywords: SPOC; Teaching model; Mobile phone; University student; Special motor course
\end{abstract}
\begin{abstract}
Nowadays, mobile phone is very convenient for people to communicate. At the same time, there have been some problems. In particularly, the negative impact on university students is greater. That's affecting their learning and life. It looks good if we can find any effective way to change this situation. Now we narrate the SPOC teaching model reform made by the Electric Drive Department of Beihua University's. Through our practical experience, we give a solution to the problem of students' uninterrupted playing with their mobile phones. In this paper we explain what is SPOC first. Then we describe the process of construction and utilization of the SPOC teaching resources. Then we elaborate the results achieved by the survey, that the positive effect SPOC made on University Students' use of mobile phone. Facts prove that the network teaching resources which are closely to the construction of campus teaching, can efficaciously guide students to use moble phone for study.
\end{abstract}

\section{Introduction}

Today many people have become mobile phone freaks. When they pick up the phone they cannot stop the operation, especially for university students, although their course tasks are heavy. Undergraduates are lively, curious, and are filled with adolescent enthusiasm. They also have poor self-control ability. Away from the supervision of parents, and with the autonomous model of university management, they can't arrange their own time very well. Many of them indulge in the virtual network world which the mobile phones set up. That makes them deplete their energy, affects their normal learning and damages their health. While if there is such a network resource, which is just correspond to the teacher's knowledge told in the classroom, or even with a more detailed explanation and extended data links, then students can search and study whenever and wherever possibly in the mobile phone. Under the intended guidance of teachers, students will gradually take the use of mobile phone for studying, and this will become a habit. Thus they will finally use the phone to do something more significant than to play games or to chat. In this idea, our teaching team have made the SPOC teaching model reform, and made the construction of the SPOC network teaching resources. We have used it to guide the use of mobile phones for college students effectively.

\section{SPOC Teaching Model and Its Characteristics}

SPOC is also known as Small Private Online Courses. That means a small online classroom or a restricted online classroom. [1] It is a kind of improved MOOC (open online courses or massive large scale online open courses [2,3]) teaching organization form, which is put forward by many MOOC-teaching researchers when they made MOOC teaching research and exploration. [4] The premise is that we continue to have abundant network resources like MOOC, and at the same time, narrow the scope of the audience compared with MOOC. We determine the attendance list through the examination. The students only who have enough foundation and pass the test can became a SPOC member. This kind of teaching form is a very good supplement to the campus class. SPOC is proposed by Professor Armando Fawkes (Armando Fox), University of California at Berkeley first. It is actualized at Harvard University, Tsinghua University as well as other international or domestic famous universities, and achieved very good effects.[] 
First, SPOC is developed from the MOOC, the MOOC network resources was borrowed, so many of the advantages of MOOC are taken. [5] SPOC teaching still use "flipped classroom" teaching model as MOOC. The teaching process of the teacher was recorded to a video. Then it was uploaded to network for students to make online learning, so as to reduce the workload of teachers in the classroom. Thus teachers have more time to pay attention to whether students have understood the knowledge classroom. Second, SPOC learning resources is very powerful. According to different levels of students, it has corresponding learning materials of different depth.. That's in order to teach students in accordance with their aptitude and to cultivate students' self-study ability. Finally, the teaching environment has a strong monitoring function, through the use of process assessment system to judge the integrity and depth of students' learning. If the student did not complete the relevant examination correctly, he (or she) will not be able to carry out the next learning process. Above all, SPOC inherits high quality teaching advantage from MOOC. Students can arrange the learning progress according to their own energy. [6]

Why we say that compared with MOOC, SPOC is more suitable for campus teaching? SPOC is different from MOOC for all people, the audience of SPOC teaching is the students in the school. The construction of the resource is also very close to the teaching content of the school. The network information not only has a strong professional direction, but also the core content of its knowledge is closest to the exam questions at the end of term. The teaching hallmark of university teachers is that they will go out of the classroom after class quickly. It is not convenient for students to ask questions at any time. Although the existing online resources are rich, but the information especially close to the school's teaching content is not enough and direct. SPOC teaching resources just make up for this deficiency. Its teaching resources are according to the specific requirements of the school teaching settings. It is also including the key and difficult points and interpretation, key exercises. It makes a mutual fit to the students' learning content in school. It is bound to be more interested for students in visiting the SPOC teaching resources, if they want to follow the teacher and learn this course goodly. Nowadays the most convenient way of information search is not a computer, but a mobile phone in the pocket. So students will frequently use the phone to assist learning. They then gradually can not do without the help of the phone. $[7,8]$

\section{SPOC Teaching Model and the Construction of Resources}

Our teaching team has taken special motor course as a case, carried out the reform of SPOC teaching research. We strive to break the situation that mobile phone does not leave the hand, and the situation that students do not concentrate on class, but addict to the network.

Special motor course is a major elective course, for the students majoring in electrical engineering and automation. The total teaching hours before reform are 40, including 34 hours of theoretical teaching and 6 hours of experimental operation.

We mainly study the teaching organization form of SPOC. And To prepare a rich online teaching resources, to develop effective student selection mechanism, and to put forward a reasonable measure of students performance evaluation are what we simultaneously worked for.

Network resources construction is divided into 3 modules: the elective assessment module, the teaching resources module and the performance evaluation module.

Our team first carried out the overall plan of the SPOC teaching organization form. First of all, the original teaching time is re allocated, the classroom is divided into two modes, online and offline. The course re arranged is still retained 40 hours. Hours allocation is shown in Table 1. 
Table 1 Hours allocation of the special motor course

\begin{tabular}{|c|c|c|c|}
\hline Item name & class house[45mins] & Content of courses & Teaching condition \\
\hline $\begin{array}{l}\text { On line theory } \\
\text { learning }\end{array}$ & 22 & $\begin{array}{l}\text { Complete online learning } \\
\text { of theoretical knowledge }\end{array}$ & $\begin{array}{l}\text { SPOC network } \\
\text { platform; theoretical } \\
\text { teaching video }\end{array}$ \\
\hline $\begin{array}{l}\text { Online } \\
\text { Experimental } \\
\text { learning }\end{array}$ & 2 & $\begin{array}{l}\text { Complete on line learning } \\
\text { of three experiments }\end{array}$ & $\begin{array}{c}\text { SPOC network } \\
\text { platform; } \\
\text { experimental teaching } \\
\text { video }\end{array}$ \\
\hline $\begin{array}{l}\text { Classroom } \\
\text { discussion }\end{array}$ & 10 & $\begin{array}{l}\text { Complete the stage } \\
\text { learning report, and the } \\
\text { discussion of the key and } \\
\text { difficult points of } \\
\text { theoretical knowledge }\end{array}$ & $\begin{array}{l}\text { Classroom; } \\
\text { blackboard, and } \\
\text { multimedia } \\
\text { courseware }\end{array}$ \\
\hline $\begin{array}{l}\text { Experimental } \\
\text { operation }\end{array}$ & 6 & $\begin{array}{l}\text { Complete } 3 \text { experimental } \\
\text { operations, and discuss } \\
\text { the difficult questions of } \\
\text { the experiments }\end{array}$ & $\begin{array}{c}\text { Motor Drive } \\
\text { Laboratory; related } \\
\text { laboratory equipment; } \\
\text { blackboard, and } \\
\text { multimedia } \\
\text { courseware }\end{array}$ \\
\hline
\end{tabular}

In SPOC teaching, the contents of this semester are divided into five knowledge blocks:

(1) Introduction and speed measuring generator (alternating-current generator and direct-current generator).

(2) Servo motor (alternating-current generator and direct-current generator).

(3) Stepping motor.

(4) Other detection devices (Synchro and Rotary Transformer).

(5) Other drive components (brushless direct-current motor, linear motor).

Theoretical[9] and experimental[10] video online were recorded about 24 teaching-hours, which one teaching-hour equals to forty-five natural minutes, With the chapter introduction and the explain of th key or difficult points as the main content. As an auxiliary, the necessary basic knowledge and expanded knowledge resources are uploaded. Students have to visit network to learn the online part of the course with mobile phones or computers. The tutorial has the function of monitoring the learning online. The webpage will pop up human-computer dialogue periodically, prompt the student to click. If there is no operation, the video can not continue. We also set up the promotion question function. At necessary time point the question is asked to test whether the audience has catch the knowledge.

Classroom discussions are arranged for five times in total, for two teaching-hours per time. In each time we complete the stage learning report about one of the five blocks told abovely, and have the discussion of the key and difficult points of theoretical knowledge. The process of the meeting course also has the consciousness to guide the students' habits of using their mobile phones. For example, the plan of the meeting class, the problem expected to solve, the preparation students should make before the class, and their tasks in class, etc, are all released online. And the questions students have met duaring study are still collected on the network platform. In the course of the meeting, we also set up a certain tasks, guide students to use mobile phones to assist learning.

On account of the experimental operation skills training can not be replaced by the online teaching, the six hours field experiments have been holden. Because the students are our own, field operations in the laboratory have become a possibility, and have no difficulty. But the relevant introduction and explanation of the experiment, as well as the need to prepare, are released in advance on the network. 


\section{Effect of the Special Motor Course SPOC Teaching Reform}

The teaching team has built a complete online teaching resources, and provides students with the experience of SPOC teaching model. Students can use their phones to carry out the course selection and take part in the qualification examination online. The one pass the examination can formally enter the special motor course SPOC learning. We call them audience-students.

The audience-students to arrange the study time and study schedule first. The online resource of SPOC course is set up with the knowledge point as the unit. Knowledge points are divided into three levels: new knowledge, related basic knowledge, and expanded knowledge. The students' knowledge base and interests affect their learning content and learning progress. Students can choose their own, with completing the necessary tasks of the curriculum as the premise. Students can complete the above setting and learning by using mobile phones or computers. Advanced resources improve students' learning effect, and strong network learning supervision means and complete assessment methods force students to complete their studies. Although these students are not in the classroom, but they can login the SPOC teaching platform through mobile phones, learn the knowledge, and get the required credits. The students can make the academic learning uninterruptedly whenever they are in the car, on the road, in the bedroom, or far away in different places. This is particularly important for the seniors. Because one's deceased father grind, job fairs and other reasons, these students are often in different places, and the absence of curriculum is inevitable in the past.

Through this comprehensive resources building and teachers' guiding, the frequency of students' using phone for learning is increased. Students' mobile phones are no longer just a boring tool for playing. Putting aside the desire for knowledge, even under pressure to get credit, they will open the phone and keep up with the progress of the study. The click rate and use rate of our SPOC teaching network are very high, and the frequency of resources download is also surprising. In the past after class, students were often holding a cell phone to read the novel or play games. After the use of SPOC teaching, we have a survey of mobile phone usage of students during the meeting-class break, and get the results as shown in Fig. 1, the wathet color histogram. Under the traditional teaching model, students' usage of the mobile phone in class is shown in Fig. 1, the navy color one. A refers to the students are not in the classroom during break, B refers to the ones stay in room but don't use phones. $\mathrm{C}$ refers to the guys use phones to play, and D refers to the ones use phones to study.

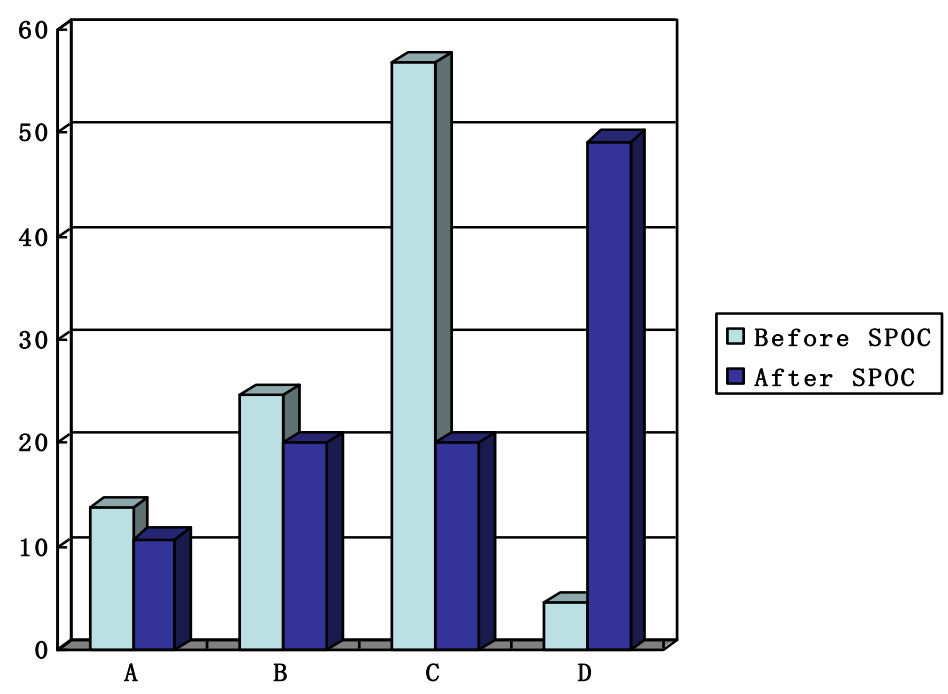

Figure 1. Proportional histogram for mobile phone

The comparison shows that, due to the inertia in class, the SPOC audience use mobile phone to browse study resources mostly. They know where to get a quick and effective answer directly, which increases the power and confidence of students to use mobile phones to learn. We know that long time behavior will become a habit. If there is a learning connection on his mobile phone desktop, and he 
recently clicked on this link regularly, then it will become a habit for him to pay attention to it. Just as we often do not have any purpose, but are used to hanging the QQ first after open the computer. As long as the network resources are good enough, are close to the learning needs, then they will play an important role in helping students to learn, and guide their habits of using mobile phones.

\section{Conclusion}

Now our team has only carried out the SPOC teaching model reform and the teaching resources construction of the special motor course. There are still some problems to be improved. For example, the expansion of the depth and breadth of learning resources, how to adjust the assessment mechanism and platform functions, so that more teaching process can be online, and so on. The more perfect the teaching environment is, the stronger the students depend on it. In addition, we will also sum up the experience of the reform and construction process, and discard the dross and select the essential, as soon as possible to use it to the construction of other courses.

\section{References}

[1] H.D. YIN: Design of SPOC Teaching Platform in the Post-MOOC Period, Journal of Jiangsu Open University, Vol. 26 (2015) No. 4, p.44-50. (In Chinese)

[2] L. Li: The Research on National Policies to Supporting the Development of MOOC, Modern Education and Teaching, Vol.24 (2014) No.5, p.67. (In Chinese)

[3] P.J. Guo, J. Kim and R. Rubin: How Video Production Affects Student Engagement: An Empirical Study of MOOC Videos, Acm Conference on Learning, Vol.43 (2014) No.2, p.13-14.

[4] B. He, Y. Cao: SPOC: MOOC-based Innovation of Teaching Processes China Educational Technology, Vol. 338 (2015) No.3, p.22-29. (In Chinese)

[5] Y.T. Qiao, Q.L. Bao and L. Zeng: A Research on Innovation and Inspiration of Higher Education Management Mode in the "Internet +" Era, Journal of Higher Education Research, Vol. 38 (2015) No.4, p.83-87. (In Chinese)

[6] J. Baggaley: Reflections on the Upsurge of MOOC, Open Education Research, Vol. 20 (2014) No. 1, p.43. (In Chinese)

[7] S.f. Chen, Y. g. Li, and S.Z. Qiu: Investigation on SPOC Teaching of Ideological and Political Theory Course in Colleges and Universities: Taking Taishan Medical University as an Example, China Educational Technology \& Equipment, Vol. 20 (2016), p.5-9. (In Chinese)

[8] L.F.Hu,X.L. Zhang: "SPOC+ Flipped Classroom" Teaching Model Application in Teaching of Higher Vocational Computer Major, Fujian Computer, Vol. 42 (2016), p.81-82. (In Chinese)

[9] Y.Q. Yang: Control Motor(China Machine Press, China 2012), p.1-7.

[10] G.Q. Sun, S.J. Yu: Control Motor, Special Motor and Thereof Control System (Peking University Press, China 2012), p.343. 